\title{
Crimes of Mistaken Identity
}

An international crime syndicate that preyed on the unsuspecting residents of Alexandria turned up in Egyptian cinema in the 1930s. Under the cover of a company known as Sharikat naqal al-amwal, the Corporation for the Transport of Capital, thieves printed counterfeit bills, burgled the bourgeoisie, and bilked families out of their savings. The police repeatedly succeeded in breaking up this crime ring thanks to the efforts of infiltrators mistaken for members of the organization's inner circle.

Unlike the protagonists of the film Raya wa-Sakina (Raya and Sakina, Salah Abu Sayf, 1953), who were based on infamous serial killers targeting bejeweled women on the streets of the Labban neighborhood in Alexandria during the first two decades of the twentieth century, the exploits of the Corporation for the Transport of Capital were not true crime stories. The Corporation for the Transport of Capital is a fictional entity that featured in two comedies directed by Togo Mizrahi and produced in his studio in Alexandria: Al-Manduban (The Two Delegates, 1934) and Khafir al-darak (The Neighborhood Watchman, 1936).

The plots of both films revolve around the misguided efforts of lower-class characters to support themselves financially. Through a series of misidentifications, the protagonists are drawn into the criminal exploits of the Corporation for the Transport of Capital. The corporation's illegal money-laundering operations are a sinister distortion of the Levantine "agent of exchange." Eventually the protagonists take advantage of their mistaken identities to assist the police in apprehending the criminals.

The films highlight Alexandria's diversity by pairing protagonists that hail from different religious or ethnonational groups. In The Two Delegates, Chalom, a Jew, and 'Abdu, a Muslim, seek to earn enough money to wed. In The Neighborhood Watchman, 'Usman, who is Nubian, and 'Azuz, who is Lebanese, try to find a steady source of income after 'Azuz's shop is burgled. In both films, the innocent 
duo inadvertently stumble into the gangster plot. In this chapter, I argue that The Two Delegates and The Neighborhood Watchman provide a framework of law and lawlessness through which members of Alexandria's minorities productively participate in Egyptian society. My analyses of the two films unpack the masquerades that unmask the criminals' plots and lead to the restoration of order and justice.

Togo Mizrahi's films privilege fluid notions of collective belonging over legalistic definitions of nationality and citizenship. In their attention to law and lawlessness, The Two Delegates and The Neighborhood Watchman focus on the actions of the police, who maintain and restore order. Courtroom dramas were not common in 1930s Egyptian cinema, nor did films depict the complicated legal system that adjudicated cases based on the citizenship of the parties involved. ${ }^{1}$ The pluralism signified by the characters' friendships in these films derives its authenticity from its homegrown character.

I begin the chapter with a discussion of Levantine farce. I lay out how both farce as a genre and the Levantine cinematic idiom subvert social norms. With their focus on the plight of the urban lower classes, Mizrahi's films articulate a particular form of national belonging-a salt-of-the-earth characterization known as ibn al-balad. In the second section below, "Chalom: A Jewish Ibn al-Balad," I argue that Mizrahi's films seek to broaden the category of ibn al-balad. The construct is usually applied only to Muslims. Mizrahi's films, though, expand the notion to include Jews. In the final two sections of the chapter, "Language of Belonging, Language of Disguise" and "Masquerade and the Levantine Carnivalesque," I argue that The Two Delegates and The Neighborhood Watchman define and assert local subjecthood in dialogue with evolving discourses of national identity, nationality, and citizenship. In these films, Levantines subvert social codes and notions of national belonging, but they are also depicted as civic-minded and law-abiding subjects who work for the common good.

\section{THE SUBVERSIVE POTENTIAL OF LEVANTINE FARCE}

The Two Delegates and The Neighborhood Watchman are farces constructed from a series of loosely connected, episodic, character-driven sketches propelled along by misunderstandings and mistaken identities. The Concise Oxford Companion to the Theater defines farce as a "form of popular comedy in which laughter is raised by horseplay and bodily assault in contrived and highly improbable situations. ... It deals with the inherent stupidity of man at odds with his environment." ${ }^{2}$ Modern farces are often constructed around "an absurd situation, generally based on extramarital adventures-hence "bedroom farce."”

Although farce is a popular form of comedy, critics often disparage the genre. When Togo Mizrahi's farcical films were released, they received mixed reviews in the press. While one critic called Mizrahi's dialogue "clever" and his jokes 


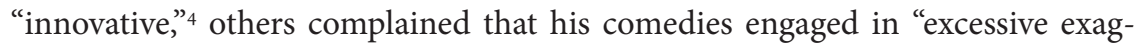
geration"s and "failed to transcend clowning."

In subsequent decades, Egyptian film historians have tended to side with farce's detractors. For example, in a survey of Egyptian film genres published in 1996, 'Ali Abu Shadi offers a scathing appraisal of Togo Mizrahi's comic films. Abu Shadi was a prominent Egyptian film critic who held a number of influential positions, including director of the National Film Center (2001-8) and state censor (1996-99; 2004-9).7 In Abu Shadi's assessment, although "Mizrahi's films were very popular and successful at the box office, and they made their stars famous," they featured "contrived and exaggerated" plotlines and lowbrow humor. ${ }^{8} \mathrm{He}$ continues: "These films are light comedies, there is no character development, no motivation for action, and no subtlety to the words. They seek only to amuse and entertain, and some are farces using mistaken identity and misunderstanding as their primary means of arousing laughs."

Abu Shadi's critique of Togo Mizrahi's farces is consistent with his assessment of genre cinema in general, and of 1930s and 1940s Egyptian comedies in particular. Abu Shadi views genre cinema, including farce, as inherently conservative -expressing "dominant mores and ideology" and affirming "the status quo and its existing values." ${ }^{\prime \prime}$ Abu Shadi contends that Egyptian farces and light comedies of the era, including those by Mizrahi, hewed closely to formulas established by Egyptian comic theater and Hollywood. These comedies, he dismissively notes, "copied, adapted, Egyptianized, and took whole scenes from" Hollywood films."

Although I take a more favorable view of Togo Mizrahi's films than Abu Shadi, I do not dispute some of his basic contentions. Mizrahi's plots of mistaken identitylike all farce-are indeed "contrived and exaggerated." Mizrahi's films also reflect the influence of Hollywood-from content, such as gangster plots, to visual style, such as continuity editing. In The Two Delegates and The Neighborhood Watchman, Mizrahi integrates elements of the gangster genre with comedy, romance, and musical performance in a manner particularly reminiscent of the Marx Brothers' Monkey Business (Norman McLeod, 1931).

I take issue, however, with Abu Shadi's foundational assumption that farce is socially conservative. Farce-"a veritable structure of absurdities," according to critic Eric Bentley-is constructed as an ongoing series of unsettling revelations. Compared with comedies, in which all is revealed in a climactic scene, "in farce, unmasking occurs all along," according to Bentley. This process of unmasking is frequently directed at subverting the tenets of religion, marriage, and moral social codes. ${ }^{12}$

Mikhail Bakhtin also views farce as disruptive. For Bakhtin, farce-like parody and satire- "function[s] as a force for exposing" standards and norms. ${ }^{13}$ Bakhtin's writings about the novel have been adapted and widely employed in cinema studies. ${ }^{14}$ In particular, film studies scholars have drawn upon Bakhtin's notion of the carnivalesque, with its practice of masquerade and unmasking. Bakhtin derives 
his notion of the carnivalesque from practices of medieval carnivals that invert power relations and subvert authority. The topsy-turvy nature of the carnivalesque elevates the grotesque and the "lower bodily stratum" over social codes of decorum. ${ }^{15}$ Representations of the carnivalesque-like farce-can reproduce these subversive tendencies.

Robert Stam points to a range of ways Bakhtin's carnivalesque is expressed in cinema, including "films that use humor to anarchize institutional hierarchies ... or direct corrosive laughter at patriarchal authority" and "films that comically privilege, whether visually or verbally, the 'lower bodily stratum."' ${ }_{16}$ Further, the features of farce that appear culturally conservative to Abu Shadi should instead, according to Robert Stam, be read against the grain. As Stam notes: "In a political culture, and a commercial film industry, where radical alternatives have been more or less ruled 'out of bounds' it is not surprising that 'subversion' often takes the apolitical form of comic aggressions that violate respectable decorum and decent standards of bodily behavior." ${ }^{17}$ According to Stam, cinematic transgressions of "good manners"-like the humor in Marx Brothers movies-should be analyzed as acts of subversion.

Togo Mizrahi's films deploy the subversive potential of farce to reflect, lampoon, and critique Egyptian culture and society. ${ }^{18}$ I argue that the social codes subverted in Togo Mizrahi's comedies include parochial notions of national identity. According to intellectual historians Israel Gershoni and James Jankowski, the 1930s saw the rise of "supra-nationalism" in Egypt-movements that defined Egyptianness in terms of a broader, "supra-national" Arab or Islamic identity. ${ }^{19}$ These ascendant nationalist strains increasingly excluded resident non-Muslim minorities, like Togo Mizrahi himself. Further, in the interwar period other exclusionary nationalist discourses such as Greek irredentism, Italian Fascism, and Zionism also circulated among some members of Egypt's resident foreign minority communities, dividing them from one another and from the majority culture.

By contrast, through the 1930s and 1940s Egyptian cinema-including Togo Mizrahi's films-projected a religiously, ethnonationally diverse national imaginary. Egyptian cinema of this era offers an implicit-if not explicit-rejection of "supra-nationalist" perspectives expressed in the press. Cinema resisted deterministic trends by embracing what I call a "Levantine cinematic idiom."

The term "Levantine," as introduced in chapter 1, refers to cultural admixture, and to individuals whose identities transcended sharply drawn ethnonational boundaries and collective identities. The terms "Levant" and "Levantine" are intentionally and necessarily vague. As a geographical term, the boundaries of the Levant are indeterminate, unruly. The term "Levantine" originally referred to residents of the eastern Mediterranean of European origins. Indistinct from the outset, the term "Levantine" evokes the vagueness of its application, and the fluidity and inherent indefinability of the people whom it identifies. As Anat Lapidot-Firilla writes in the inaugural issue of the Journal of Levantine Studies, "As it developed 
alongside colonial practices and Eurocentric attitudes, the term, like other 'culturally impure' terms, acquired derogatory connotations." ${ }^{20}$

I come to the term "Levantine" through the work of Egyptian-Jewish essayist Jacqueline Shohet Kahanoff. Writing in 1950s and 1960s Israel, when fears of cultural admixture espoused by the Ashkenazi Zionist leadership were derogatorily dubbed "Levantinization," Kahanoff embraces and reappropriates the term. Drawing upon her experiences growing up in interwar Egypt, Kahanoff calls for actively adopting the Levantine as a model for constructing Israeli society. Thanks to Kahanoff's writings, the term "Levantine" has evolved into an adjective describing a social formation or cultural force. In Kahanoff's writing, the Levantine becomes an agent of exchange. ${ }^{21}$

By applying the term "Levantine" to cinema, I aim to highlight the transnational nature of filmmaking. While film industries developed along national lines, film is inherently a collaborative medium. It is also a traveling and transnational medium. Further, the term acknowledges the ways many individuals associated with film industries-like Togo Mizrahi-challenge restrictive constructions of national identity.

I employ the term "Levantine" to analyze 1930s and 1940s Egyptian cinema as a locally situated project reflecting a pluralist ideal. I am not suggesting that the term "Levantine" (or its equivalents in Arabic, French, Italian, etc.) would have had currency in 1930s Egyptian film criticism-either among Egyptians or the resident minorities and foreigners..$^{22}$ Rather, I have adopted "Levantine" to index the vagueness and porousness of the boundaries of identity that the term evokes.

Levantine films share several characteristics. First, these films' representations of Egyptian pluralism reflect and engage with an ethics of coexistence. To be clear, while Levantine farces represent Egyptian diversity, they do not necessarily feature a plot that promotes a pluralist agenda. For example, Togo Mizrahi's Chalom and Abdu films The Two Delegates and Mistreated by Affluence quite evidently espouse an ethics of coexistence. By contrast, in The Neighborhood Watchman, the friendship that develops between Nubian and Lebanese characters appears as an incidental detail within an episodic plot structure.

Second, Levantine films utilize cinematic tools to construct a pluralist aesthetic. Like the carnivalesque Shamm al-nasim montage from Mistreated by Affluence discussed in chapter 1, many scenes in Togo Mizrahi's 1930s comedies were shot on location in Alexandria's streets, cafés, beaches, parks-sites where people came in contact with one another. In The Two Delegates, Chalom and 'Abdu-a Jew and a Muslim, respectively-stride out of a café together arm in arm (fig. 9). The 1937 film Al-Sa'a 7 (Seven O'Clock), discussed in chapter 5, opens with a lengthy, all-encompassing traveling shot through the busy streets of central Alexandria. In these scenes the camera's inclusive gaze underscores the pluralist ethics of the diegesis. 


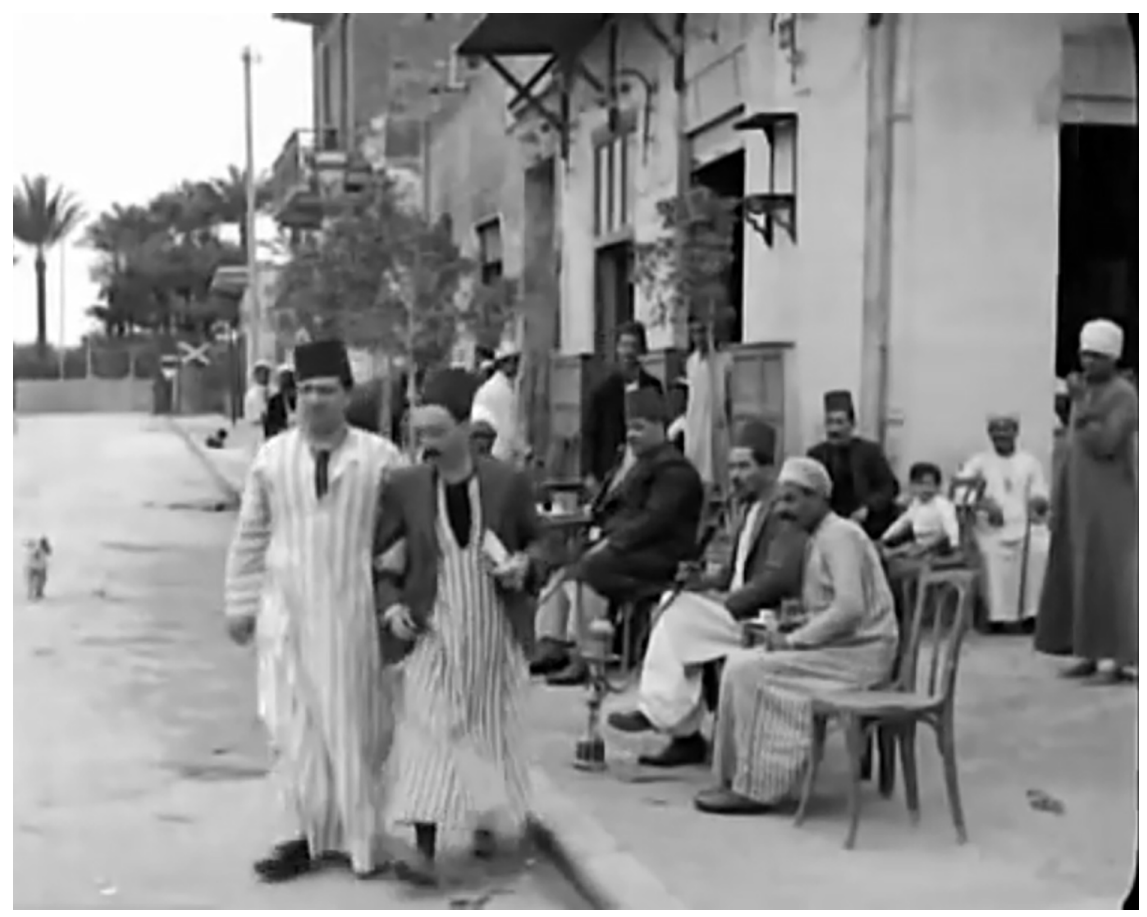

Figure 9. 'Abdu ('Abdu Muharram, left) and Chalom (Leon Angel) leave a café arm in arm. Screenshot from The Two Delegates (Togo Mizrahi, 1934).

Third, Levantine films foreground the performativity of identity. Plots of mistaken identity highlight the fluid and mutable character of identity as performance: they do not merely arouse laughs, as Abu Shadi contends. My analyses of mistaken identity and masquerade reveal the plot device's subversive potential.

The Levantine cinematic idiom is evident in a range of genres in 1930s and 1940 s Egyptian cinema, and in films produced by a number of different studios. In this chapter and the two that follow, I examine Levantine farces written, directed, and produced by Togo Mizrahi.

As already noted, critics like 'Ali Abu Shadi dismiss 1930s and 1940s genre films as decadent and derivative of Hollywood. ${ }^{23}$ Nationalist critics of Egyptian film have also favored socialist realism over comedy, viewing melodrama as the vehicle best suited to a cinema of substance. As a genre, melodrama has the capacity to reveal social ills. It was also the genre of choice for depicting the anticolonial struggle. As Joel Gordon demonstrates in Revolutionary Melodrama, Egyptian melodramas produced following the 1952 Revolution articulate, enact, and disperse ideologies of the postcolonial Egyptian state. ${ }^{24}$ I argue that, in contradistinction to "revolutionary melodrama," Levantine farces articulate, enact, and disperse ideologies of pluralist nationalism. 
In Togo Mizrahi's 1937 film Mistreated by Affluence, a boarded-up shop front is plastered with advertisements for his earlier film Awlad Misr (Children of Egypt, 1933). I argued in chapter 1 that the self-referential (and self-promotional) posters for Children of Egypt in a film about friendships between Muslims and Jews asserted an inclusive notion of nativeness. More specifically, the posters served to identify Jews-including Togo Mizrahi and the character Chalom-as children of Egypt.

The film's Arabic title, Awlad Misr, evokes an Egyptian colloquial term that is used to describe the urban lower-classes: awlad al-balad (pl.; ibn al-balad, m. sing.; bint al-balad, f. sing.). In popular usage, the term ibn al-balad or bint al-balad signifies a person of simplicity, goodness, and purity of heart. Plain-speaking awlad al-balad prize themselves on their sense of humor. According to Sawsan el-Messiri, the term emerged in the eighteenth century to describe native craftspeople, distinguishing them from Turko-Circassian elites, from Arabic-speaking immigrants from outside of Egypt, and from foreigners. ${ }^{25}$ The terms "ibn al-balad" and "bint al-balad" function as markers of both indigeneity and class.

The notion of awlad al-balad possesses a self-reflexive and performative quality; it does not reflect a rigid classification. A subject's baladi-ness is enacted via dress, behavior, speech patterns-in other words, through performance. Baladiness is a status of mutual belonging accorded upon recognition of shared affinities.

While el-Messiris study of the term's historical evolution passes quickly over the period during which Mizrahi's films were produced, one of her informants, a craftsman self-identified as an ibn al-balad, offers some insight into the term's associations in the interwar period. From his vantage point in the late 1960 or or early 1970s, when el-Messiri conducted her fieldwork, he notes that awlad al-balad of an earlier generation "used to attend the theater, especially the plays of Naguib al-Rihani and ['Ali] al-Kassar." ${ }^{26}$ In other words, according to el-Messiri's informant, in the early twentieth century awlad al-balad were, in part, defined by their attendance at theatrical performances that shaped and defined their sense of self.

Togo Mizrahi was actively engaged in perpetuating and disseminating this performance of identity. "Ali al-Kassar, a quintessential "ibn al-balad" of the stage, worked extensively with Togo Mizrahi. Mizrahi was instrumental in helping al-Kassar bring to the screen his popular stage persona: 'Usman 'Abd al-Basit, a down-on-his-luck Nubian. ${ }^{27}$ Between 1936 and 1944, al-Kassar starred in nine films directed by Mizrahi, including The Neighborhood Watchman.

Although Mizrahi and al-Rihani never made a film together, al-Rihani's longtime writing partner, Badi' Khayri, collaborated with Mizrahi on several films, including writing the lyrics to the songs featured in The Two Delegates. Naguib al-Rihani had a long stage career leading a popular theater troupe, and a successful star turn on the silver screen. ${ }^{28}$ Naguib al-Rihani's most famous character, Kish 
Kish Bey, is a mayor of a fictional village called "Kafr al-Balas." Despite his association with this lower-class notion of collective belonging, both al-Rihani's onstage Franco-Arab Revue and the film projects with which he was associated represent Egyptian diversity across classes. ${ }^{29}$

Togo Mizrahi's socially conscious films produced in his Alexandria studio between 1930 and 1939 feature two other comic stars who also portray lower-class characters: Fawzi al-Gazayirli and Chalom, who appear together in the film The Two Delegates. Fawzi al-Gazayirli frequently played a shop owner named Bahbah, and other simple characters of limited means. In addition to his featured role as Amina's father in The Two Delegates, al-Gazayirli appeared in Al-Bahhar (The Sailor, 1935) and starred in Al-Duktur Farhat (Doctor Farahat, 1935), discussed in the next chapter. After a five-year hiatus, in which he appeared in several films written and directed by his son Fu'ad, Fawzi al-Gazayirli returned to Studio Mizrahi to appear in two comedies directed by Togo Mizrahi: Al-Bashmaqawil (The Chief Contractor, 1940) and Al-Fursan al-thalatha (The Three Musketeers, 1940). ${ }^{30}$

Chalom was the screen name and on-screen persona of Leon Angel, an Alexandrian Jew of Greek nationality. Unlike other film comics of his era, most of whom started their careers in comedy troupes, Leon Angel had no experience onstage. ${ }^{31}$ Angel developed the character "Chalom" for the screen. He starred in three films directed by Togo Mizrahi: 05001 (silent, 1931), The Two Delegates, and Mistreated by Affluence. Angel is credited as assistant director of The Two Delegates. Angel went on to direct two additional films in which he also starred. In 1935, Angel forged out on his own to direct and star in Chalom al-turgaman (Chalom the Dragoman), which was shot at Studio Alvise Orfanelli. ${ }^{32}$ His second film, Al-Riyadi (The Athlete, 1937), was shot at Studio Mizrahi and produced by the Egyptian Films Company. Angel pseudonymously codirected The Athlete with Clément Mizrahi, Togo's first cousin and brother-in-law. ${ }^{33}$

In The Two Delegates, Chalom sells lottery tickets in the streets and cafés. His sidekick, 'Abdu ('Abdu Muharram), is a butcher's assistant who suffers at the hands of his employer. Angel's character, Chalom, challenges commonly held assumptions about both nativeness and Jewishness in 1930s Egypt. The terms " ibn al-balad" and "bint al-balad" have generally applied only to the Muslim majority. I argue that Togo Mizrahi's Chalom and 'Abdu films expand the notion of awlad al-balad to include lower-class, Arabic-speaking Jews.

In addition to broadening the notion of nativeness held by the populace at large, the character Chalom also unsettles perceptions of arabophone lower-class Jews held by the francophone Jewish bourgeoisie. In dress and speech Chalom shares traits common among the Jews from the popular districts in Cairo and Alexandria. Members of the Jewish bourgeoisie, and those with upwardly mobile bourgeois aspirations, spoke French and dressed in Western fashion. The Egyptian Jewish bourgeoisie looked down upon the poverty and traditional religious values characteristic of the residents of Harat al-yahud, Cairo's medieval Jewish quarter. 
Many also spurned the use of Arabic. ${ }^{34}$ They never saw themselves as embracing the identity of the ibn al-balad that Chalom represents..$^{35}$

A response to Chalom's on-screen persona that appeared in the Jewish press illustrates and complicates this class and cultural divide. Following the release of the second Chalom and 'Abdu film, Mistreated by Affluence, in 1937, Raphael Mosseri, a reader of the Arabic-language Egyptian-Jewish newspaper Al-Shams, wrote a letter to the editor complaining that the film debases Jews. While he appreciated the portrayal of amity between "two Egyptian families living in Egypt-one Jewish and the other Muslim," Mosseri found Chalom's behavior a disgrace to the community. Chalom steals meat from the butcher shop where 'Abdu works. At moments in the film, his character comes across as petulant, selfish, and stingy. Mosseri implores Mizrahi to use his great talent to avoid depicting Jewish characters with such shortcomings. Mosseri writes: "It is incumbent upon [Mizrahi] as a Jew to show the virtues of his fellow Jews, ennobling their appearance on the silver screen." ${ }^{36}$ Mosseri, an arabophone Jew engaged in the public sphere of the ArabicJewish press, published his views in a journal that advocated for the integration of Jews into Egyptian culture. Yet Mosseri rejects Chalom. The Jewish ibn al-balad is not the role model he wishes to see on-screen.

Mosseri, however, misses the point. Chalom was not a figure for emulation. Like Charlie Chaplin's tramp, Chalom holds a mirror up to society. Chalom, the ibn al-balad, reflects Togo Mizrahi and Leon Angel's desire to articulate a particular vision of Jewish belonging within the Egyptian polity. The character Chalom boldly inserts lower-class, arabophone Egyptian-Jewish nativeness into the cultural imaginary.

\section{LANGUAGE OF BELONGING, LANGUAGE}

OF DISGUISE: THE TWO DELEGATES (1934)

Togo Mizrahi's The Two Delegates illustrates these distinctions between arabophone Jewish awlad al-balad and the local francophone foreign-minority residents. The film, I argue, depicts both of these groups as part of the cultural fabric of the city, in contradistinction to incomprehensible "foreigners." The film also portrays a locally situated, Alexandrian culture of coexistence. I argue that the film foregrounds cultural practices shared by Jews and Muslims. In particular, the representations of Chalom's and 'Abdu's weddings highlight these shared rituals and downplay differences of religious rite.

Chalom, a Jewish peddler of lottery tickets, wishes to marry Esther (Esther Angel, credited as 'Adalat);37 and 'Abdu, a Muslim butcher's assistant, seeks to wed Amina (Siham). Both women are products of middle-class families with bourgeois aspirations. ${ }^{38}$ When Chalom and 'Abdu extend proposals of marriage, they are rejected by the brides' mothers on class grounds (fig. 10). Independently, both prospective mothers-in-law identify the suitors' native garb-the galabiya-as a 


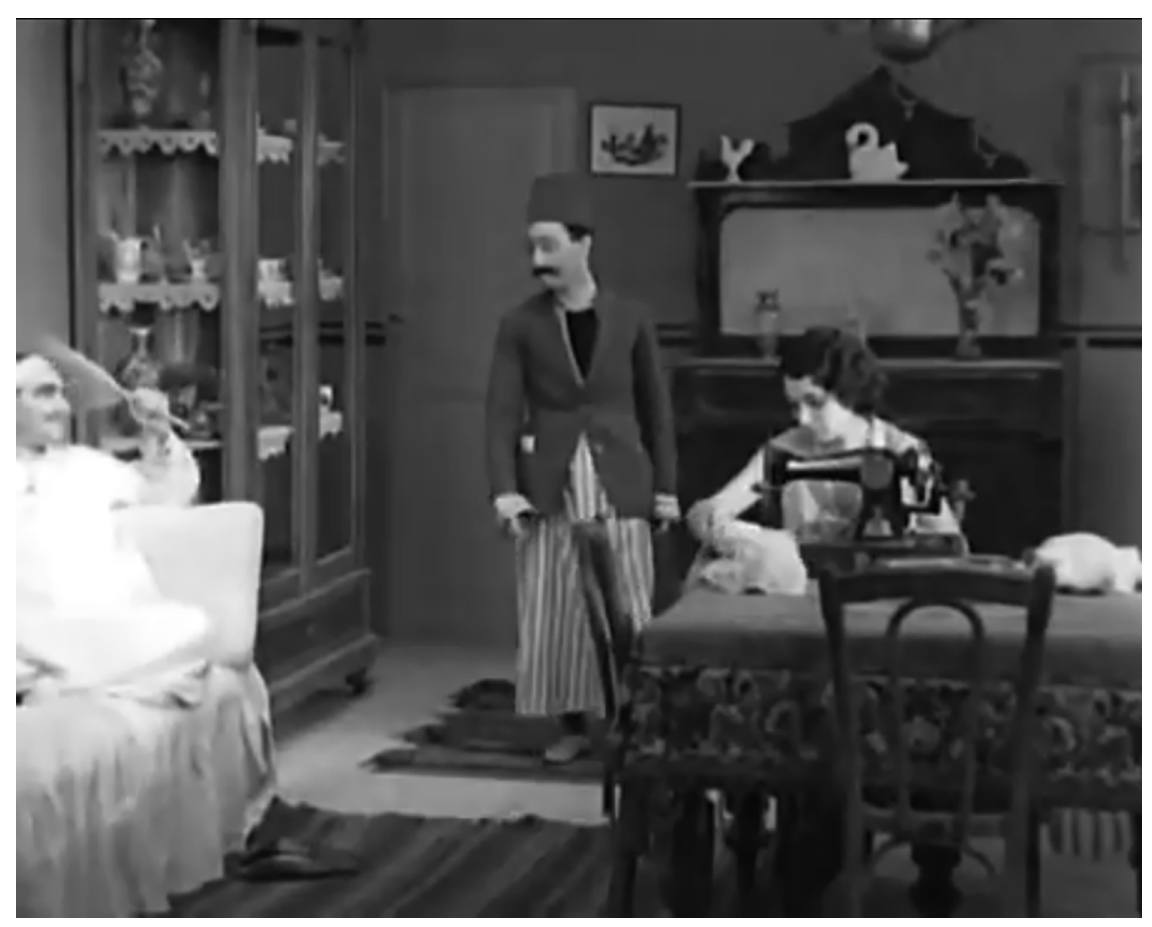

FIGURE 10. Chalom (Leon Angel, center) comes to ask Solomon (Muhammad al-Salamuni, left) to marry his daughter, Esther (Esther Angel, credited as 'Adalat). Screenshot from The Two Delegates (Togo Mizrahi, 1934).

sign of poverty and backwardness. The protagonists' adventures throughout The Two Delegates are motivated by their desire to marry.

This narrative of becoming an effendi-a term that, according to Lucie Ryzova, reflects education, dress, and, to a certain extent, class-was playing out in Egyptian spaces both domestic and public, as well as on the Egyptian screen. ${ }^{39}$ Chalom and 'Abdu strive to meet the middle-class expectations of their future in-laws. The two dejected friends set out to purchase a suit and tie to replace the scorned galabiya. By changing their appearance, Chalom and 'Abdu are engaging in a form of masquerade. The scene in the tailor's shop where they buy the suits highlights the disjuncture between their sense of self and their appearance; the sight of 'Abdu trying on a top hat sends the two friends into a fit of laughter. Dressed in a Western suit and tarboosh, Chalom and 'Abdu can pass as members of the effendiyya.

The change in costume also sets the two friends up for the case of mistaken identity that renders the film a Levantine farce. After purchasing the suits, Chalom and 'Abdu slip into a barbershop for a shave. When they leave the barbershop, they mistakenly don the wrong suit jackets-ones bearing lapel pins that identify them as members of an international organized-crime outfit (fig. 11). A local band of 


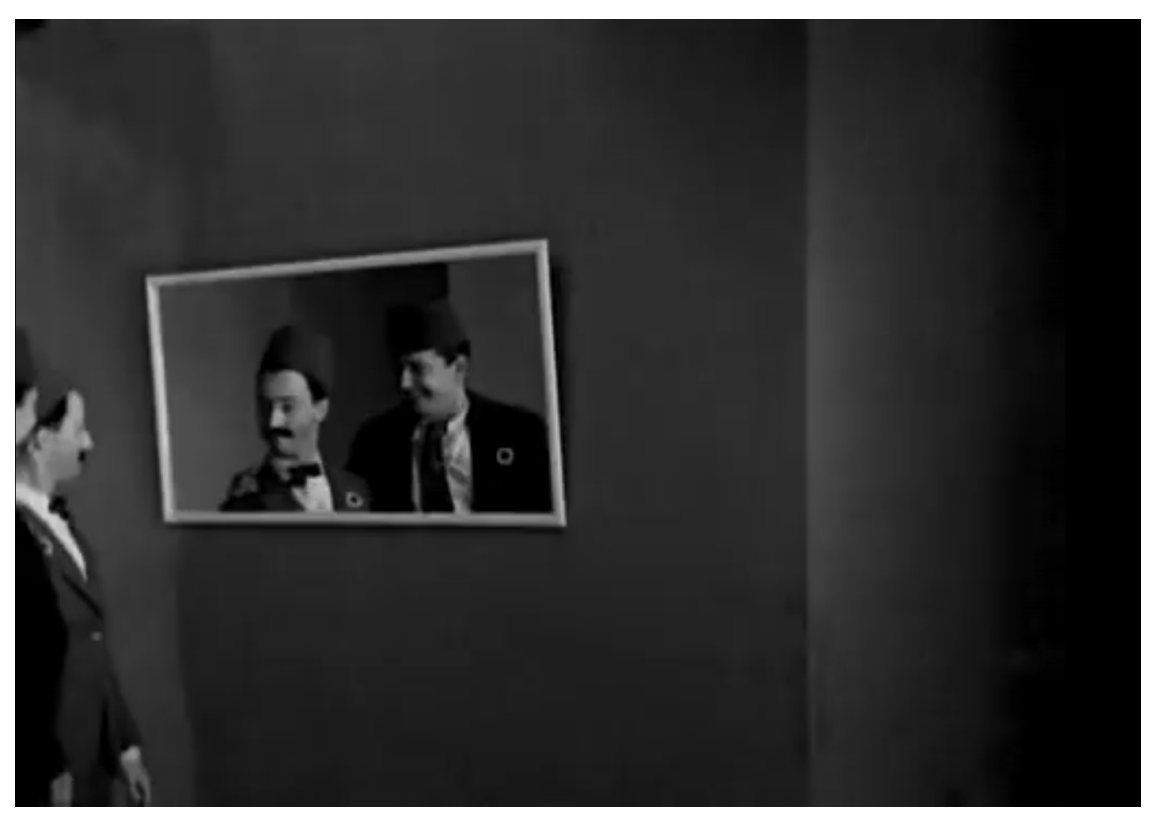

FIGURE 11. Chalom (Leon Angel, left) and 'Abdu ('Abdu Muharram) notice the insignia on their lapels. Screenshot from The Two Delegates (Togo Mizrahi, 1934).

thieves, under the cover of the Corporation for the Transport of Capital, is anticipating the arrival of two delegates from abroad. World-renowned safecrackers, the international representatives have been brought in to review the corporate books (!) and to oversee a covert operation. Chalom and 'Abdu are mistaken for the visiting delegates and gain access to the organization's secret lair.

The Two Delegates is the earliest surviving film directed by Togo Mizrahi. He had made the transition from silent to sound in Children of Egypt, his feature released the previous year. The Two Delegates retains a heavy reliance on the physical comedy of the silent era. They key moments in Chalom's and 'Abdu's transformation and their mistaken identification as the delegates all take place without words. The scenes are shot silent and played with accompanying nondiegetic music. The barbershop scene where Chalom and 'Abdu put on the wrong jackets is accompanied by a rousing instrumental rendition of "Puttin' on the Ritz." The scene cuts to a female representative of the organization awaiting the arrival of the two delegates on a street corner in al-Manshiyya, the commercial center of Alexandria. She flirtatiously flashes the organization's secret gesture. Chalom, flirting back, mimics the gesture. She beckons, and the two men follow. The interaction on the street, conducted without words, is accompanied by instrumental Arabic music.

Miscommunication like the misinterpretation of nonverbal symbols-the pin and the gesture-sets up comic misunderstandings that serve to highlight 
particular characteristics of the film's construction of native Egyptianness. Mizrahi also explores failures of communication: the alienation of confronting foreign languages. These miscommunications serve to underscore the identity of the protagonists as plain-speaking, lower-class residents of popular quarters-awlad al-balad-who, in the popular imagination, represent authentic Egyptianness. By reviewing these comic miscommunications, I would like to draw attention to the distinction between speakers of foreign languages and (presumed) foreigners. I argue that The Two Delegates establishes two discourses of otherness. The first, defined by class and language difference, is locally situated, familiar, and culturally comprehensible even in its unfamiliarity. The characters who speak French are portrayed as local residents who expect their address to be received and understood. The second form of otherness, by contrast, is enacted by gibberish-speaking locals pretending to be foreigners. The imaginary "foreigner" they represent is one of radical otherness.

In The Two Delegates, language-both the language and idiom spoken and the mode of address-also signals communal identification. In The Two Delegates, when Chalom first enters the apartment of Esther's parents, he greets them with the Hebrew phrase "Shalom 'Alekhem" - also a play on his name. Chalom, Esther, and most of Mizrahi's other Jewish characters speak the same urban Egyptian Arabic dialect that their Muslim counterparts do. The character Vittoria (Vittoria Farhi), Esther's mother, employs a number of expressions that linguist Gabriel Rosenbaum has identified as distinct to Egyptian Jews. ${ }^{40}$ Jewish audiences were attentive to Vittoria's dialogue, although they were not necessarily supportive of Mizrahi's portrayal of a Jew as speaking differently from their neighbors. In the letter to the editor of al-Shams discussed above, Raphael Mosseri complained that Vittoria's manner of speaking was an exaggerated affectation. ${ }^{41}$

A lengthy massage-parlor scene in The Two Delegates illustrates the first form of miscommunication-between Arabic-speaking and French-speaking locals. Chalom and 'Abdu repeatedly demonstrate that they don't speak or understand European languages commonly heard on the streets of Alexandria. In the course of a chase scene in which they are trying to escape from one of the criminal thugs, Chalom and 'Abdu seek refuge in a posh massage parlor. The receptionists, manager, and clientele all speak French, while the massage therapists are a linguistically mixed lot. The accented French of one of the clients and the massage therapist, Marie, for example, suggests that they are Alexandrian Greeks. ${ }^{42}$ Misunderstandings abound. 'Abdu is taken for a job applicant. Chalom is presumed to be a client.

At first glance, it would be easy to dismiss this comic interlude as sensationalism, an excuse to show some skin. Nearly twelve minutes long, this scene features no less than three women in various states of undress. Further, this lengthy excursus has little direct bearing on either the romantic plot or the gangster narrative.

However, I would like to suggest that this scene serves to establish the nexus between language and class, illustrating the valences attached to Arabic and French 
in this film. The series of miscommunications in this scene between the protagonists' Arabic and their interlocutors' French serves to draw attention to particular characteristics that define their nativeness. Poor and uneducated, but bearing the street smarts, charm, and good humor of awlad al-balad, Chalom and 'Abdu speak exclusively Egyptian Arabic. French is a language associated with the bourgeoisie. It is also the common language among noncitizen local residents, including the foreign minorities.

The film verbally indexes the miscommunication that plays out throughout the scene. When the manager ushers the new hire, 'Abdu, into a treatment room, he provides instruction in French. Then he turns to 'Abdu, rhetorically inquiring, "Compris?"- that is, "Understood?" He leaves without receiving a response. 'Abdu shrugs and mutters to himself in Arabic, "Ana ma fahimtish wa-la haga" ("I didn't understand a thing") - a sentiment he repeats several times throughout the scene. The manager incorrectly assumes the addressee to be a French speaker who would understand the plain meaning of his spoken utterances, as well as an experienced massage therapist who would possess the appropriate lexicon to assimilate his specific technical instructions.

This scene places Arabic-speaking protagonists from humble origins in contact with local residents who belong to, aspire to, or provide services for the francophone bourgeoisie, to whom the massage parlor caters. The protagonists eventually manage to overcome linguistic barriers with the francophone women in the treatment rooms and the mixed, unfamiliar social codes of physical contact between sexes. ${ }^{43}$ With the gestural guidance of his client, 'Abdu manages to learn some massage technique on the spot. The scene ends when the spa director, in a trilingual tirade ["à la porte"; "fayn al-flus?"; "door"], throws Chalom out when he can't pay for his massage.

The second form of miscommunication - an utterance intended to confuse or deceive-is, by contrast, intentionally insurmountable. In The Two Delegates this incomprehensible address takes place during the first encounter between the protagonists and the band of thieves. Seated at the head of a conference table, surrounded by his underlings and across from the visiting delegates, the local crime boss - in a nod to Hollywood gangster films-reports (in Arabic) on recent activities, summarizes the annual take, and pays tribute to their members who were killed. He notes to his members that the visiting delegates do not understand Arabic, so they must communicate with signs. During the course of this meeting the crime boss invites 'Abdu to address the local membership in his own language, "Globes-talk." 'Abdu obliges by animatedly launching into a gibberish monologue. ${ }^{44}$

In The Two Delegates, Jewish and Muslim characters are depicted as EgyptianArabic-speaking local subjects. Chalom and 'Abdu, in particular, share many of the qualities associated with awlad al-balad. The experiences of lower-class Egyptian Muslims and Jews are one and the same. The locally situatedness of these 
characters is further cemented by the presence of two forms of otherness: the francophone cosmopolitan bourgeoisie; and foreigners (as enacted by gibberishspeaking locals masquerading as foreigners).

The francophone cosmopolitan bourgeoisie, while lacking the native authenticity of the arabophone Levantines-Muslims and Jews alike-nevertheless constitute part of the local landscape. Foreigners, as imagined — and mimicked—by the locals, are portrayed as uncomprehending and incomprehensible intruders into the local social fabric. In Mizrahi's films, Jews are not portrayed as part of either of these categories. The Two Delegates vaunts a native authenticity derived from a relationship to language (Arabic) and place (Alexandria). The film articulates a locally situated pluralism that minimizes markers of difference.

The friendship and collaboration between Chalom and 'Abdu-Jew and Muslim-also contributes to the restoration of order and justice. At the end of the film, Chalom and Abdu return to the headquarters of the Corporation for the Transportation of Capital and fight two of the criminals. When the crime boss hears the commotion, he and his lackeys go to investigate, giving an undercover police officer the opportunity to call for backup. The police arrive, and the criminals are apprehended. Back at the station, the police chief thanks Chalom and 'Abdu for helping to capture this dangerous band of criminals. He presents them with a cash reward for their efforts. The windfall - coupled with their earlier wardrobe upgrade-makes it possible for Chalom and 'Abdu to wed Esther and Amina.

Despite its episodic digressions, the plot of The Two Delegates builds toward the dramatic conclusion of the dual weddings. After Chalom's and 'Abdu's proposals are turned down, two mysterious, wealthy-looking suitors extend proposals of marriage to Esther and Amina. The suitors woo the future mothers-in-law with the promise of financial security. The "suitors" are actually members of the Corporation for the Transport of Capital. They con the families into turning over their savings. Only after a visit by a police investigator do the families learn of the deception and the loss of their money.

Chalom and 'Abdu's reward-equivalent to the amount Esther's and Amina's families squandered on the fake suitors-prompts the families to accept their proposals of marriage. Despite their windfall and their new wardrobe, Chalom and 'Abdu are no more financially secure than they were at the beginning of the film. They have not secured civil-service jobs that would ensure their place among the rising middle class, the effendiyya..$^{45}$ The Two Delegates offers an early cinematic representation of the process Lucie Ryzova calls "becoming efendi," which includes, but is not limited to, dressing the part ${ }^{46}$ The mere appearance of Chalom and 'Abdu's class mobility - their performance of identity - meets the families' equally hollow class aspirations. Chalom and Esther, and 'Abdu and Amina, wed in the final scene of the film.

The wedding scene is shot to visually emphasize the close friendships between the film's Jewish and Muslim characters. The narrative of coexistence is mirrored 
in the Levantine aesthetic of the wedding montage. In the film's final scene, the nuptials occupy one minute of screen time, and are presented entirely without dialogue. The wedding scene begins with the sound of ululation that signals the families' acceptance of the marriage proposals and carries over to a shot of festive decorations outside the house. The scene cuts to Amina in her wedding gown as we begin to hear the sound of the $z a f f a$, the wedding procession, accompanied by a brass ensemble known as a Hasaballah band. ${ }^{47}$ The music plays in a continuous, unbroken stream over a montage of wedding images featuring both couples.

In this scene, Togo Mizrahi depicts only shared idioms of celebration. It is perhaps not surprising that Mizrahi chooses weddings to represent shared cultural practices. In a study on Middle Eastern popular culture, Sami Zubaida offers wedding ceremonies as an example of the confluence of popular religious practice that cuts across confessional groups. ${ }^{48}$ The scene in The Two Delegates reflects wedding celebrations as practiced in Egypt's cities, including both traditional elements and Western attire that reflects bourgeois class aspiration. ${ }^{49}$

The Two Delegates does not, however, depict religious elements of the wedding ceremonies. A similar absence is particularly apparent in the longer, more extensive montage of Chalom's and 'Abdu's nuptial festivities that appears in Mistreated by Affluence, including a celebration welcoming the delivery of furniture to the future home of the bride and groom; a henna ceremony; communal preparation of food for the wedding feast; seating of the bride and groom facing the guests at the wedding party; and a processional, led by musicians and a dancer, escorting the newlyweds out of the party toward their new home. Yet, there is no huppah and breaking of a glass; no handshake accompanied by the recitation of the Fatiha. ${ }^{50}$ The absence of wedding ceremonies in Mizrahi's films is entirely in keeping with the common practice in Egyptian cinema of that era. Couples announced their plans to wed, and films featured wedding parties. Yet in the context of Mizrahi's lengthy, detailed representation of other traditions that are also not generally depicted on-screen, the absence of wedding ceremonies is striking.

Both The Two Delegates and Mistreated by Affluence rapidly intercut between the two celebrations in honor of Chalom and Esther and of 'Abdu and Amina. This technique serves to blur distinctions between the Jewish and Muslim weddings. By representing the celebrations in this way, the nuptials serve to underscore the films' ethics of coexistence-their representation of deeply intertwined communities of Jews and Muslims coexisting as equals. ${ }^{51}$

\author{
MASQUERADE AND THE LEVANTINE \\ CARNIVALESQUE: THE NEIGHBORHOOD \\ WATCHMAN (1936)
}

In The Neighborhood Watchman, 'Ali al-Kassar plays his signature role, 'Usman 'Abd al-Basit, a poor Nubian immigrant to the city. "Usman is a simple, good-hearted, 
and honest-but luckless—character. Despite his best efforts, 'Usman can't hold a job. At the beginning of The Neighborhood Watchman, 'Usman is employed as domestic servant for a member of the foreign-minority elites. Preparing for a banquet, 'Usman is charged with transporting a large tray of food to a bakery for baking in its large oven. En route, hungry birds descend upon the tray, making off with some of the food. When Usman returns to the home of his employer, he is berated, beaten, and kicked out. The episodic plot of the film follows this formula: 'Usman pursues increasingly contrived - and humorous-employment opportunities; and each failure is met with verbal lashings or physical beatings. Yet when confronted with an opportunity to earn money through illicit means, 'Usman refuses.

Over the course of the film, 'Usman is regularly mistaken for someone else. The title of the film is derived from a series of nested masquerades in which 'Usman is mistakenly hired to serve as a neighborhood watchman. The film then takes a carnivalesque turn as 'Usman and his sidekicks try their hand at popular forms of entertainment. The film ends with a body-double plot as 'Usman is mistaken for the crime boss of the Corporation for the Transport of Capital. The subversive potential of The Neighborhood Watchman lies in its Bakhtinian, carnivalesque inversions of power and authority.

In The Neighborhood Watchman, the police serve as the figures of authority, charged with protecting the populace. But over the course of the film, 'Usman's actions erode this authority. At the beginning of the film, when birds steal food from 'Usman's tray, he humorously tries to report the "theft" to the police. But the officer he contacts berates 'Usman and tosses him out of the station for making a mockery of justice.

'Usman's employment as a night watchman - the title role of the film-is the result of a double case of mistaken identity: he is first given someone else's job, then sent on assignment under another's name. 'Usman's nagging and abusive wife, Umm Ibrahim (Zakiya Ibrahim), reports him to the police commissioner, accusing him of negligence. 'Usman is hauled into the station. 'Usman does not know the reason for the summons, and concludes he must be under investigation for stealing meat from his former employer. While he is awaiting his fate, 'Usman bends the ear of Ba'za'(Ahmad al-Haddad), who has come seeking employment as a night watchman. ${ }^{53} \mathrm{Ba}^{\prime} \mathrm{za}$ ' has handed over his letter of introduction and is waiting to be interviewed. In the first mix-up, 'Usman is invited into the police chief's office and is offered the job, while Ba'za' is called into the assistant's office and given a stern warning. When Ba'za' emerges, confused, his wife intercedes, and the police chief eventually offers him a job, too.

The second mix-up occurs after 'Usman and Ba'za' show up together for training as night watchmen. 'Usman and Ba'za' are called in for a medical exam. The doctor's assistant inquires about their identity and seems confused when their names do not correspond to the names on his sheet: Muhammad 'Issa and Ali Abu Zayd. When the assistant steps out, 'Usman and Ba'za' poke around the exam 
room. Ignoring the poison sign on the medicine cabinet, they sniff an open bottle and then steal fistfuls of something that looks like candy. When the assistant returns, their mouths are full and they can only grunt when he inquires again about their identity. Thinking they are Muhammad 'Issa and 'Ali Abu Zayd, he dismisses them for assignment.

'Usman's masquerade as a guard causes a breakdown of the public trust when a crime occurs on his watch. 'Usman and Ba'za' are stationed in the vicinity of a store owned by 'Azuz (Hasan Salih), a shami (Levantine Arab) merchant. The thieves, members of the Corporation for the Transport of Capital, implement a diversionary tactic. A female member of their organization, dressed in traditional attire, approaches 'Usman and Ba'za' in distress. She eventually manages to convey that her husband has disappeared and implores them to help her locate him. While they attend to the distressed woman, the thieves are left free to rob 'Azuz's store without arousing suspicion.

At precisely this juncture, when 'Usman's masquerade as a watchman is poised to erode the authority of the police, the film takes an explicitly carnivalesque turn. The film does not depict the thieves at work, nor does it show the efforts of 'Usman and Ba'za' to assist the woman in distress. Instead, the scene cuts to a second encounter, disrupting the narrative flow between depiction of the watchmen's ineptitude and their dismissal from their jobs. This carnivalesque scene is inserted without context, and without any clear motivation within the diegesis.

A clock strikes two; then the scene fades to a doorway from which masquerading revelers are slowly-and noisily-emerging. Two tall figures in full head masks appear (fig. 12). Meanwhile, 'Usman and Ba'za' cower on a bench, trying to convince one another that they are not afraid of the dark. The costumed revelers spot the anxious guards and decide to give them a fright. Standing partially in shadow, the pranksters remove their masks. As their heads are obscured by black cloth, from the perspective of the frightened guards it looks like the figures have removed their heads. Ba'za' exhorts 'Usman to "be a man." Unconvincingly bragging of his own bravery, Ba'za' is rendered speechless by the approaching headless apparitions. The revelers then silently trade "heads" and then rest them on a bench. As the frightened guards grasp on to one another and shuffle away, the camera zooms in on two wet spots on the bench and the visible urine stains on their backsides.

Mizrahi's comedies do not shy away from lowbrow antics. Scatological humor sold tickets (and still does). 'Ali Abu Shadi specifically cites Mizrahi's willingness to include such scenes as evidence that Mizrahi was a commercial filmmaker who produced entertainment devoid of social value. ${ }^{54}$ However, by contrast, I read this scene as an articulation of the destabilizing potential of the carnivalesque. Mikhail Bakhtin asserts that "downward movement is inherent in all forms of popular festive merriment." "The mighty thrust downward" of the carnivalesque draws our attention to "the material bodily lower stratum." 55 Bakhtin writes: "Down, inside 


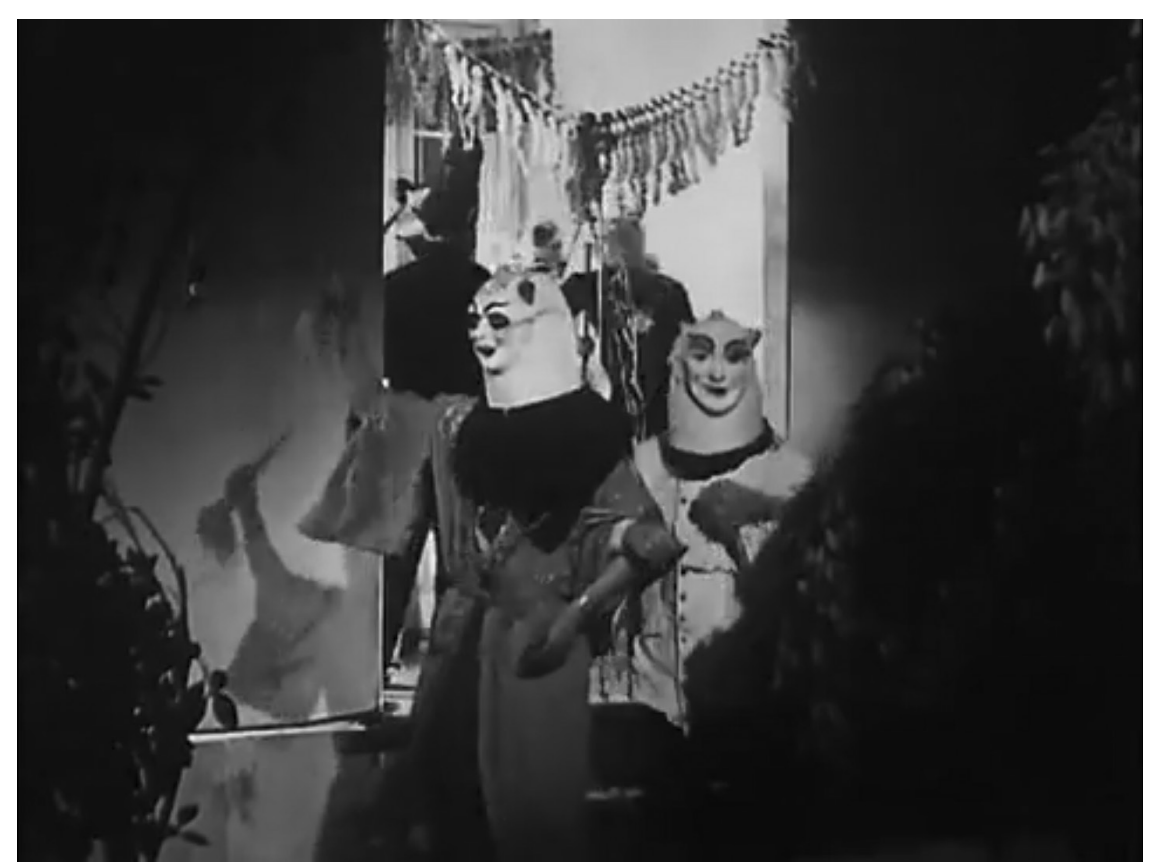

FIGURE 12. Revelers leave a costume ball. Screenshot from The Neighborhood Watchman (Togo Mizrahi, 1936).

out, vice versa, upside down, such is the direction of all of these movements. All of them thrust down, turn over, push headfirst, transfer top to bottom and bottom to top, both in the literal sense of space and in the metaphorical meaning of the image." ${ }^{56}$ The conclusion of the masquerade scene may cross the boundaries of good taste. But, following Bakhtin, we can read this elevation of the vulgar and debasement of the cinema as an embrace of the subversiveness of carnivalesque farce.

The prank is also transformed into a self-referential joke when it is revealed that one of the masked revelers is Togo Mizrahi himself. The pranksters briefly remove their masks in the street, and their discussion about spooking the guards takes place with their faces exposed. Thus, Togo Mizrahi's cameo in this scene in particular-his identity revealed by removing a mask-indexes the Levantine idiom of masquerade and the subversive threat posed by Levantine performativity of identity.

The prank scene also functions as a narrative hinge; up until this point, the Egyptian Ba'za' was 'Usman's sidekick, but following the theft, 'Usman's fate instead gets tied up with that of the robbed shami shop owner, 'Azuz. After the theft, 'Azuz and his Egyptian wife (Zuzu Labib), a singer, lose their apartment. 'Usman's wife also kicks him out after he loses his job. Together, the Nubian former watchman, the shami former shop owner, and the Egyptian singer find two rooms in a shared 


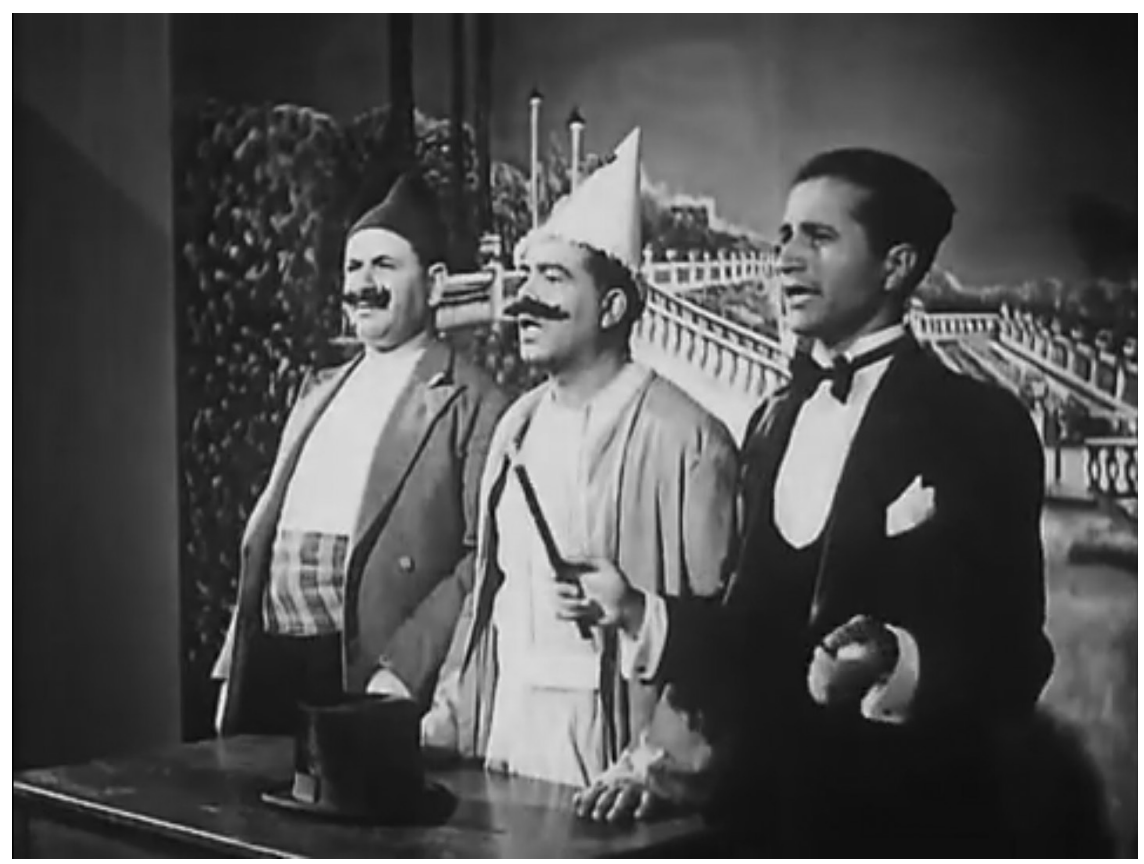

FIGURE 13. 'Azuz (Hasan Salih, left) and 'Usman ('Ali al-Kassar, center) work as magician's assistants. Screenshot from The Neighborhood Watchman (Togo Mizrahi, 1936).

hovel. This way, too, the prank scene signals the transgressive intersection of the carnivalesque and the Levantine.

The carnivalesque atmosphere persists as 'Usman and 'Azuz seek employment. 'Azuz's wife returns to the stage to help support her family. A magician performing in the same variety show hires 'Azuz and 'Usman as his assistants (fig. 13). 'Usman appears onstage in a clownish pointed hat and an oversized fake moustache. Although 'Usman tries to play it straight, the audience laughs and jeers at his antics. Ever the fool, 'Usman bungles the first trick by unwittingly revealing the magician's secret to the audience. 'Usman and 'Azuz are then summarily dismissed. Meanwhile, Ba'za' tries his luck performing in the streets with a dancing monkey. These carnivalesque performances, while not themselves subversive, index the subversive potential of the performance of Levantine identities elsewhere in the film, including the film's concluding episode, which involves inverted identities.

Eventually, 'Usman and 'Azuz are drawn into a con by the same band of thieves who had robbed the shop. A representative of the Corporation for the Transport of Capital offers 'Usman and Azuz a job. They share the information with their struggling friend Ba'za'. The three men are provided with large banknotes, and asked to fan out over the city to make change. The innocent job seekers do not 


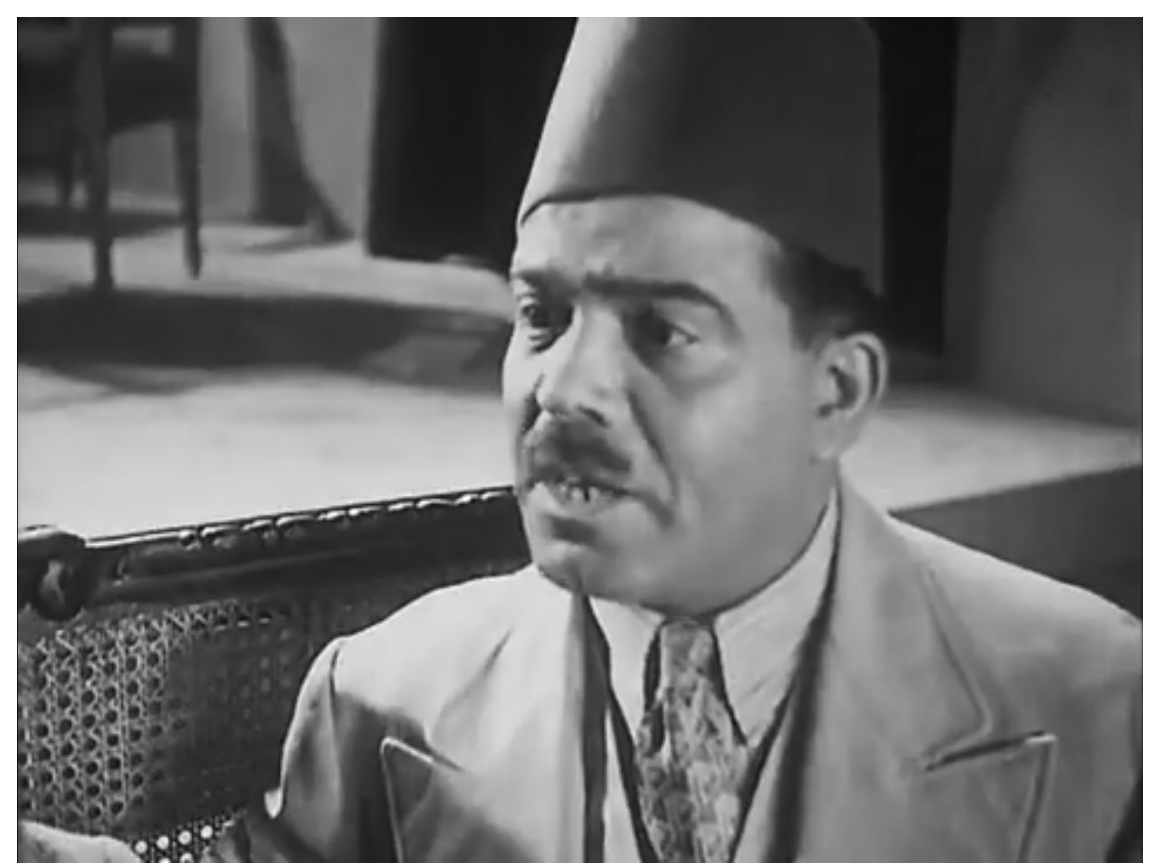

FIGURE 14. 'Ali al-Kassar in his double role as the crime boss. Screenshot from The Neighborhood Watchman (Togo Mizrahi, 1936).

comprehend that they are helping to circulate counterfeit bills printed by the gangsters. They are unwitting agents of exchange.

This false currency exchange is then mirrored in the final act of mistaken identity. It turns out that 'Usman resembles the crime boss (also played by al-Kassar; fig. 14). When the members of the Corporation for the Transport of Capital see 'Usman, they take him for their ruthless leader, treating him with respect and deference. Strange women vie for 'Usman's attention, thinking he is the crime boss. The plot of mistaken identity leads to a series of humorous interactions and mistaken romantic liaisons before it dawns on 'Usman that they think he is someone else.

Reading people's reactions, 'Usman comes to realize his resemblance to the boss. He also figures out that the money they were asked to change is counterfeit. He calls the police chief from the thieves' lair and reports the crime. When the police eventually arrive at the scene, the crime boss assumes 'Usman's identity to elude capture. 'Usman's wife, Umm Ibrahim, arrives, but she cannot initially distinguish between the two men: she mistakenly unleashes her wrath on the crime boss instead of her husband (fig. 15).

Umm Ibrahim devises a plan to reveal the men's true identity. She demands a moment in private with each man. She then positively identifies her husband. 


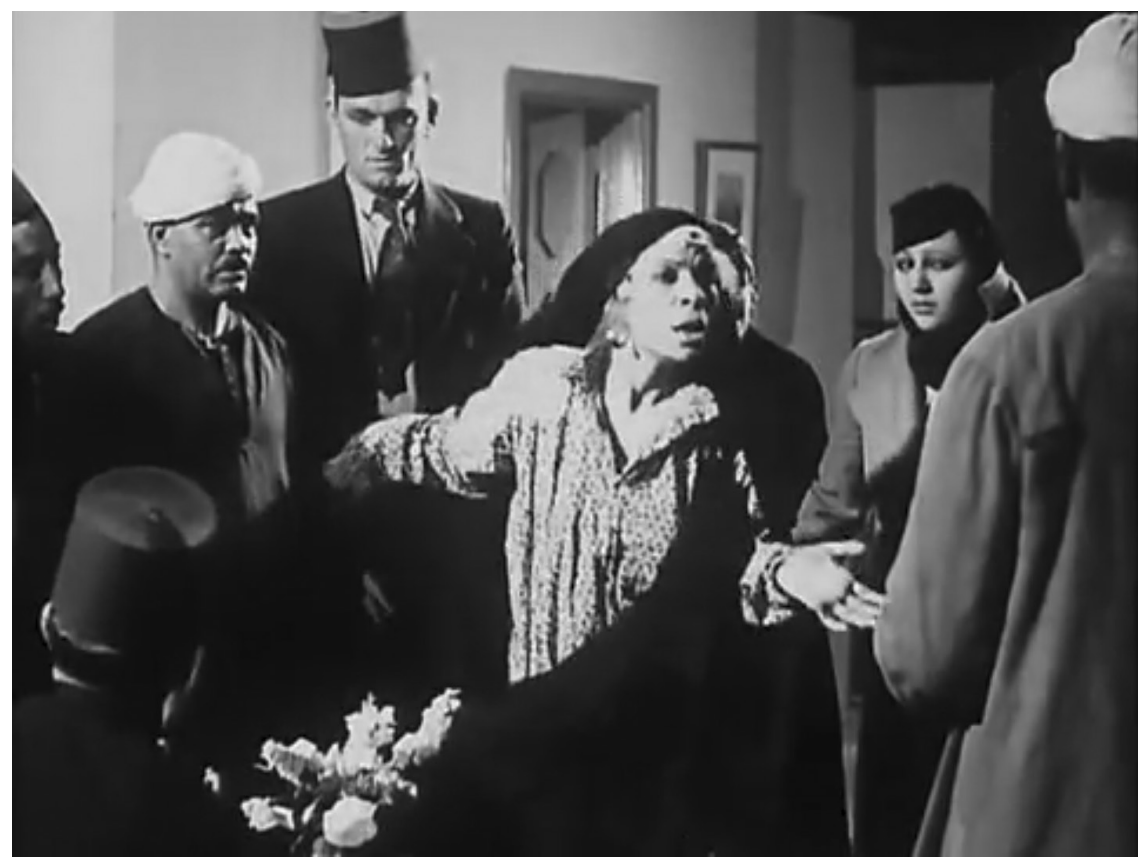

FIGURE 15. Umm Ibrahim (Zakiya Ibrahim, center) cannot distinguish between the crime boss and her husband, 'Usman ('Ali al-Kassar, left). Screenshot from The Neighborhood Watchman (Togo Mizrahi, 1936).

The crime boss is apprehended. 'Usman and Umm Ibrahim are reconciled. And, thanks to his role in assisting the arrest, 'Usman is reinstated in his former job as a night watchman.

The ethical behavior (and cunning) of the Levantine characters working together thwarts lawlessness. In The Neighborhood Watchman, disruptions presented by the Levantine idiom are unmasked as harmless-mere pranks or apparitions that may seem threatening but pose no real danger. The film instead vaunts the power of coexistence, of Levantine ethics, to combat crime that threatens the livelihoods of hardworking Alexandrians of all classes and backgrounds.

\section{CODA: LEVANTINE MASQUERADE \\ AND SUBVERSIVE SEXUALITY}

Togo Mizrahi was not the only filmmaker producing Levantine films in Egypt. Nor are The Two Delegates and The Neighborhood Watchman the only films produced in 1930s Egypt that explore the subversive potential of Levantine masquerade through the unmasking of criminal activity. Take, for example, in the 1936 film Zawja bi-l-niyaba (Wife by Proxy, Ahmad Galal), in which a violent crime sets 


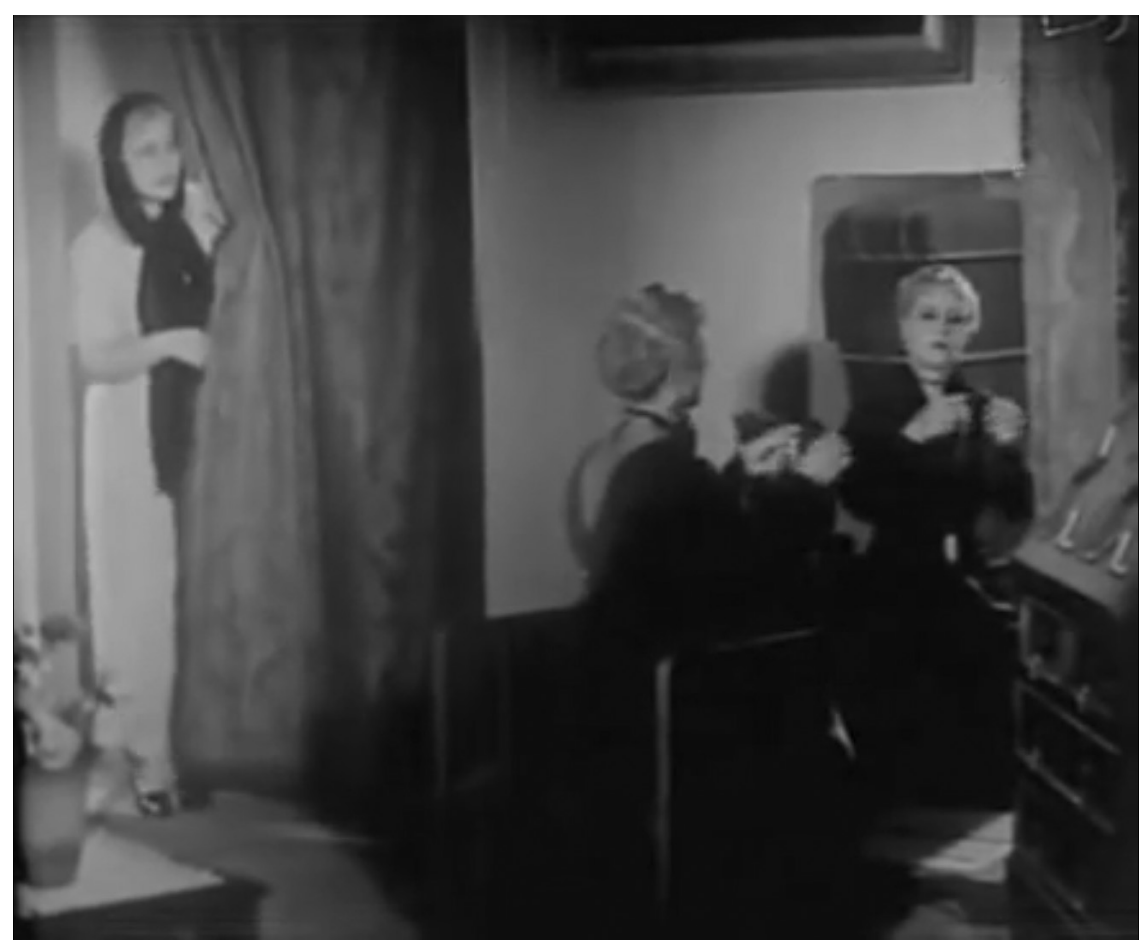

FIGURE 16. Nahid (Assia Dagher) watches Amina (also Assia Dagher) put on jewelry. Screenshot from Wife by Proxy (Ahmad Galal, 1936).

into motion an extended masquerade. In Wife by Proxy, Nahid (Assia Dagher), a Lebanese country girl fleeing an arranged marriage, stows away on an Alexandriabound passenger ship anchored in Beirut's harbor. The wealthy Egyptian Amina Hanim (also Assia Dagher) is returning home from a vacation in Istanbul. Nahid and Amina, both played by Assia Dagher, of course resemble one another (fig. 16). A Jewish jewel merchant named Cohen shows his wares to Amina Hanim and permits her to take some pieces back to her cabin to try on. Meanwhile, skirting away from a suspicious crew member, the stowaway, Nahid, takes refuge in Amina's cabin. There, she witnesses Amina's murder at the hands of a jewel thief. Recognizing her resemblance to the deceased, Nahid does the only sensible thing under the circumstances: she dons Amira's gown and strides into the ballroom, assuming her identity. On the boat, Nahid confronts the thief and insists that he return the jewels to Cohen. After disembarking, the thief, who has recognized Nahid, tries to blackmail her with threats to reveal her true identity. Nahid eventually metes out justice, shooting the jewel thief just as he had shot Amina.

Wife by Proxy was a production of Assia Dagher's company Lotus Films. Dagher, born in Lebanon to a Maronite Christian family, moved to Cairo in the 
1920 s in pursuit of an acting career. Dagher was a pioneer of the Egyptian film industry and remained an important film producer through the 196os. Like her many other successful films of the 1930s, Wife by Proxy was a family affair. The film featured Dagher's niece Mary Queeny and Mary's husband, Ahmad Galal, who also directed the film.

The Levantine masquerade in Wife by Proxy integrates the shami immigrant into both an Egyptian body and the Egyptian body politic. The poor Lebanese migrant fleeing from an arranged marriage finds herself assuming the identity of a wealthy, married Egyptian woman. Nahid continues the masquerade with Amina's husband, providing the opportunity for a series of comic deferrals of the couple's amorous reunion. When all is revealed, Amina's husband decides to stay together with his deceased wife's double, and the couple continue the masquerade of marriage together. Like The Two Delegates and The Neighborhood Watchman, this film explores both the subversiveness and crime-fighting power of fluid Levantine identities. But Wife by Proxy adds another twist-sexualities that disrupt the conventions of marriage. In the next chapter, I explore at greater length subversive sexualities in two of Togo Mizrahi's Levantine bedroom farces: Doctor Farahat and Mistreated by Affluence. 